\section{Nyttig håndbok}

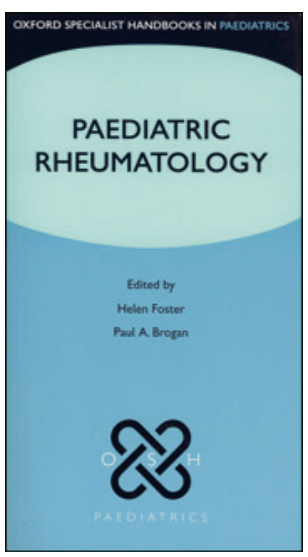

Helen E. Foster, Paul A. Brogan, red. Paediatric rheumatology

465 s, tab, ill. Oxford: Oxford University Press, 2012. Pris GBP 40

ISBN 978-0-19-959263-0

Flere britiske forfattere står bak denne utgivelsen innen barnerevmatologi. Helen Foster og Paul Brogan, som er hovedansvarlige redaktører, er velrenommerte barnerevmatologer. Når man leser, må man ta hensyn til at boken er særlig beregnet for britiske forhold. Særlig gjelder det medikamentvalg og råd med hensyn til praktisk oppfølging, som ikke alltid kan overføres direkte til norske forhold. Målgruppen er hovedsakelig leger under spesialisering innen pediatri og pediatere, men også revmatologer som arbeider med barn, og andre faggrupper som sykepleiere og fysioterapeuter $i$ behandlingsteam, er aktuelle lesere.

Forfatterne gir en bred innføring i barnerevmatologi. De ønsker å hjelpe leseren til å forstå og håndtere alle problemstillinger innen barnerevmatologi og nærliggende sykdommer, og sørger for informasjon om alt fra de aller vanligste til de helt sjeldne tilstandene. Forfatterne presenterer kort de fleste temaene og berører kun hovedpunktene, slik at teksten ikke gir særlig dybdeinformasjon. Det er imidlertid en rekke nyttige referanser til annen litteratur og nettsider med tanke på supplerende lesing.

Den praktiske paperbacken har lommeformat og er oversiktlig og lett å orientere seg i. Tabellene, illustrasjonene og bildene er mange og svært nyttige. Enkelte av fotografiene er i farger. Et helt kapittel inneholder bilder av vanlige utslett hos denne pasientgruppen. Informasjonen om normalfunn innen de ulike alderstrinnene er også oversiktlig. Forfatterne gir mange nyttige råd og god veiledning med tanke på utredning av barn med plager fra muskel- og skjelettsystemet. Oversiktene over symptomer, funn og differensialdiagnoser er gode. Særlig nyttig er flere tabeller med «røde flagg». Det er også flere oversikter over diagnostiske kriterier, klassifikasjonskriterier og kriterier for vurdering av sykdomsaktivitet og behandlingsmål. En veiledning i bruk av biologiske legemidler og syntetiske, sykdomsmodifiserende legemidler som brukes i behandlingen av leddgikt, og ved andre inflammatoriske revmatiske sykdommer (DMARD), er også tatt med. Bidragsyterne kommer også med råd vedrørende infeksjoner og vaksinering i forbindelse med denne type behandling. De gir i tillegg praktiske råd om enklere former for behandling, for eksempel behandling med intraartikulære steroider.

Jeg vil absolutt anbefale denne håndboken som et nyttig hjelpemiddel i en travel klinisk hverdag. Leseren får raskt en oversikt over aktuelle problemstillinger og om nødvendig gode anbefalinger for videre lesing.

Anne Noraas Bendvold

Revmatologene

Kristiansand

\section{Kirurgiske scenarier - kort og godt}

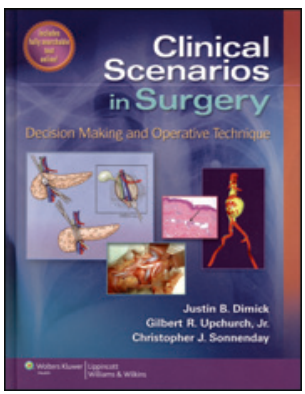

Justin B. Dimick, Gilbert R. Upchurch Jr., Christopher J. Sonnenday Clinical scenarios in surgery

Decision making and operative technique. 633 s, tab, ill. Philadelphia, PA: Lippincott Williams \& Wilkins, 2012. Pris USD 140 ISBN 978-1-60913-972-8

Tilgang på faglig informasjon, ikke minst via elektroniske kanaler, er økende. Tradisjonelle lærebøker blir stadig mer voluminøse. Både studenten, spesialistkandidaten og den mer erfarne klinikeren føler gjerne behov for å sortere, komprimere, strukturere og oppdatere sine faktakunnskaper - gjerne uavhengig av elektronisk tilgang.

I denne boken skisserer forfatterne vel 120 kirurgiske scenarier korte enkeltkapitler som tar utgangspunkt $i$ en meget kort kasuistikk. Med bakgrunn i den kliniske problemstillingen beskriver og drøfter de en rekke temaer innen generell og gastroenterologisk kirurgi, thorax- og karkirurgi, barnekirurgi og traume- og akutt kirurgi. Kortfattet og konsist, oftest på tre-fem sider, beskriver de tilstanden med tilhørende diagnostikk og behandling. Teksten avsluttes med gode «take home points», og de fleste kapitlene har nyttige illustrasjoner av god kvalitet. Et begrenset antall referanser er angitt i slutten av de fleste kapitlene. Noen forfattere kunne nok strukket seg litt lengre hva gjelder relevante og oppdaterte artikler.

Innholdet er preget av den nordamerikanske tradisjonen: Alle forfatterne kommer fra USA, med en stor representasjon fra Ann Arbor, Michigan, der også to av redaktørene arbeider. Noen få anbefalinger og kliniske veivalg er nok litt annerledes i norsk klinisk hverdag, uten at dette blir problematisk.

Boken er ikke helt liten, men godt håndterlig. Oppsett og trykk er tiltalende og leservennlig, innbindingen er solid, og selve konseptet synes jeg er spennende. Som redaktørene anfører, så er unge studenter og spesialistkandidater av i dag «multitaskere» - man sitter ikke lenger i timevis og leser i tykke bøker. Men fortsatt kan man lese for å lære. Uansett må man kunne bære med seg kunnskap og ferdigheter ut i klinikken for å gjøre jobben og for å ta ansvaret som følger med. Om man er innstilt på effektiv læring, er trolig denne boken en smart investering - selv om den ikke er påtrengende billig.

\section{Jon Arne Søreide}

Avdeling for gastroenterologisk kirurgi

Stavanger universitetssjukehus 